\title{
Progressive Acidification: An Aspect of Chemical Leaching of Sewage Sludge
}

\author{
Luke N. Ukiwe \\ Department of Chemistry, Federal University of Technology \\ P.M.B 1526, Owerri, Nigeria \\ Tel: 234-806-419-2946_E-mail: luggil2002@yahoo.com \\ Rita N. Oze \\ Department of Chemistry, Federal University of Technology \\ P.M.B 1526, Owerri, Nigeria \\ E-mail: gabrieloze@yahoo.com \\ Christopher I. A. Nwoko \\ Department of Chemistry, Federal University of Technology \\ P.M.B 1526, Owerri, Nigeria \\ E-mail: nwokochristopher@yahoo.com
}

$\begin{array}{ll}\text { Received: November 14, } 2011 & \text { Accepted: December 1, } 2011 \quad \text { Published: February 1, } 2012 \\ \text { doi:10.5539/ijc.v4n1p62 } & \text { URL: http://dx.doi.org/10.5539/ijc.v4n1p62 }\end{array}$

\begin{abstract}
The effect of progressive acidification using inorganic and organic acids in chemical leaching of sewage sludge was studied. Results of analyses using Atomic Absorption Spectrophotometer (AAS) showed that Mn was the most metal solubilized totaling 4.760 and $4.220 \mathrm{mg} / \mathrm{l}$ using $30 \%(\mathrm{v} / \mathrm{v}) \mathrm{HNO}_{3}$ and $50 \%(\mathrm{v} / \mathrm{v})$ acetic acids respectively for digestion, while $\mathrm{Cd}(0.038$ and $0.027 \mathrm{mg} / \mathrm{l})$ was the least metal extracted using $10 \%(\mathrm{v} / \mathrm{v}) \mathrm{H}_{2} \mathrm{SO}_{4}$ and $50 \%(\mathrm{v} / \mathrm{v})$ benzoic acid respectively for digestion. $\mathrm{HCl}$ was generally observed to be the best extraction medium for the metals; $\mathrm{Cd}, \mathrm{Mn}, \mathrm{Pb}, \mathrm{Ni}$, and $\mathrm{Cu}$ at all acid range 10-90\% (v/v) concentrations. However, comparing the leaching capability of both acids type, the inorganic acids were observed to be more effective than organic acids in leaching heavy metals from sewage sludge.
\end{abstract}

Keywords: Absorption, Chelates, Concentration, Digestion, Extraction, Precipitation, Solubilization, Wastewaters

\section{Introduction}

Sewage sludge (SS) is produced from the treatment of wastewaters and vary depending on the source as different wastewater sources has different constituents with varying compositions in the sludge (UNEP, 2004). The amount of sewage produced and the population size density determine the method of treatment and disposal method of the sludge. The physiochemical processes involved in SS treatment tends to concentrate heavy metals (HMs) which are toxic or poisonous constituents in the sludge even in small amounts and which can only be removed by sludge management techniques such as acid solubilization.

SS contains nutrients, organic matter, pathogens and contaminants ranging from suspended large solids through colloids to dissolved solids which have to be treated and processed to avoid prospective health risks when disposed off (Harrison \& Oakes, 2002). Processing of SS includes treatment processes that involve settling of sludge to remove solids such as fats, oils etc. A study conducted on sewage processing noted that screening, grit removal and grease removal are the first steps of pre-treatment where the solids are removed from the effluent sewage water for disposal (UNEP, 2004). HMs are bound or incorporated into the organic matter, organic mineral aggregates and inorganic particles of the sludge and poses an obstacle to its utilization, making its 
removal or extraction by physical means difficult (Morita \& Tsuboi, 2000). The chemical form of the metals is a function of the method used to extract or reduce HMs from SS. These methods of extraction include bioleaching (using microbes) and chemical (using acids). Chemical extraction involves the use of both organic and inorganic acids to extract HMs from SS. According to Yoshizaki \& Tomida (2000), the sufficient removal of HMs from sludge can only be achieved by using acids as the extracting solution, though, report suggest that using acids as extracting solution could impart adversely on the environment (Ukiwe \& Nwoko, 2010a). Nevertheless, recent studies have suggested organic acids as promising extracting agents since they are biodegradable and they yield high metal efficiency even at mildly acidic pH (Babel \& Dacera, 2006). A study conducted on the solubility of metals in SS showed that HMs extraction from SS depended on factors such as $\mathrm{pH}$, redox potential of the sludge, and the concentration of the metals and ligands (Naoum et al., 2001). Hence, in order to determine the extraction efficiencies of HMs from SS, Zhang et al. (2008) noted that in relation to the species of the metals in the sludge, the extraction efficiency depended on the sludge content, dosage of the extractants, reaction time and temperature.

Acid solubilization of HMs is a process of proton exchange from the acid to the sludge (Browski et al., 2004). After solubilization, the removal of the solubilized metals is achieved by chemical precipitation followed by a physical separation step (Stylianou et al., 2007). There are three major approaches available to reduce the concentration of HMs in SS (Marchioretto et al., 2002). Firstly, there should be control of industrial sources and other point sources where wastewaters discharge into sewer systems. Secondly, control of diffuse sources using lead $(\mathrm{Pb})$ free gasoline and, thirdly, by the extractive removal of HMs from SS. The latter process makes use of extreme acidic conditions for sufficient solubilization and release of metals to the liquid medium. The liquid containing the solubilized metals could be separated by centrifugation.

An investigation into the effect of aeration and acidification on HMs solubilization of SS using the various experimental procedures which include; aeration before acidification and aeration after acidification demonstrated that $\mathrm{Mn}$ and $\mathrm{Cu}$ were the highest metals extracted when the above experimental procedures were applied in metal extraction (Ukiwe \& Nwoko, 2010b). However, when aeration was applied only, Cu extraction efficiency dropped remarkably. $\mathrm{Ni}$ and $\mathrm{Pb}$ were effectively extracted when the aeration after acidification protocol was used. The study further revealed that the extraction yield of $\mathrm{Cd}$ was least when the aeration before acidification procedure was employed. Some studies have suggested the application of aeration and acidification procedures to achieve best condition for HMs solubilization and extraction in sludge. These authors argue that mobility and bioavailability of metals depend on their chemical forms, as such, it is important to determine metal speciation while evaluating the amounts of metals leached under changing environmental conditions (Loska \& Wiechuła, 2006). However, aeration has been reported to cause an increase in the amount of $\mathrm{Cu}$ released from organically bound forms (labile organic material) and a decrease in the organic-sulphide fraction (stable organic material) in marine sediment slurries (Gerring, 1991).

When acid is added to sludge, the HMs present in the sludge dissolves and exists in solution (Arain et al., 2009). Optimum conditions for HMs removal from sludge can be achieved through variation of contact time between the extraction agent (acid) and the sludge solution. The effect of nitric acid concentration and sonication time on the removal efficiency of HMs from sludge was also investigated by Deng et al. (2009). Results obtained indicated that when nitric acid concentrations were varied from 0 to $0.65 \mathrm{M}$ and sonication time also varied from 0 to $29 \mathrm{~min}$, the removal efficiency of $\mathrm{Cu}, \mathrm{Zn}$, and $\mathrm{Pb}$ increased with increasing nitric acid concentration and sonication time. The study also noted that sonication time of 20 min resulted in maximum HM removal efficiency. Ukiwe and Iwu (2010) attempted an investigation into the effect of reaction time and acids in chemical leaching of HMs in SS and their study revealed that effective and efficient metal extraction could be achieved when acid and sludge are reacted for a contact time of $1 \mathrm{hr}$. Though a contact time of $6 \mathrm{hrs}$ led to poor metal extraction. Also, there was no observable trend in HM extraction as contact time was ascended from 1, 2, 4 and $6 \mathrm{hrs}$ respectively. Various complexing agents such as EDTA (ethylenediamine tetracetic acid), EDDS (ethylenediamine disuccinic trisodium salt), DTPA (diethylenetriamine pentacetic acid), and NTA (nitrilotriacetic acid) have been applied to enhance metal solubility and extraction in sludge system (Ukiwe et al., 2010). Several factors should be considered when comparing chelating agents for HM decontamination. These factors include among others; the ratio of chelating/HMs (Polettini et al., 2008). Using smaller quantities of chelating agents generates competition of chelates with other complex substances found in the sludge. Addition of EDTA to sludge base on stoichiometric requirements for metals such that the percentage of metal removal by EDTA do not correspond to stability constants for the EDTA complex raises issues associated with HMs bound by various insoluble salts. EDDS has been shown to have greater rate of degradation and strong chelating characteristics than other chelating agents. Nevertheless, its biodegradation rate varies largely depending upon 
the examined conditions (Evangelou et al., 2007). Interaction experiments have demonstrated that EDTA and NTA are more efficient than malate and citrate in solubilizing metals with minimal difference in extraction efficiency between the two chelates (Peñolosa et al., 2007). Consequently, when complexing agents such as citric and oxalic acids as well as EDTA are applied to sludge, metals such as $\mathrm{Cr}$ could be solubilized at a higher $\mathrm{pH}(3-5)$ than when a strong acid such as $\mathrm{HNO}_{3}$ is applied.

The aim of the present study was to evaluate the effect of progressive acidification using inorganic and organic acids in chemical leaching of domestic sewage sludge.

\section{Materials and Method}

The sewage sample used in this study was obtained from the male hostel septic tank of the Federal University of Technology, Owerri, Nigeria. The septic tank has a capacity of about $800 \mathrm{~m}^{3} /$ day of sludge. Two $100 \mathrm{~L}$ plastic containers previously washed and rinsed with deionised water were used to collect the sewage sample from the tank. The containers were left to stand for $24 \mathrm{hrs}$ in the Project Laboratory of the Department of Chemistry, Federal University of Technology, Owerri, Nigeria. These samples form the stock solution. From these stock solutions, samples were continuously drawn for the experiment. A quantity of sample equaling $2 \mathrm{~L}$ of sewage was measured into a $2 \mathrm{~L}$ beaker previously washed and rinsed with deionised water. About $1 \mathrm{~L}$ of this sewage sample was measured into another $2 \mathrm{~L}$ conical flask and centrifuged (MC 5415C) for $2 \mathrm{hrs}$ at $150 \mathrm{rpm}$. The resulting solution was filtered through Whatman No. 42 filter papers. To $30 \mathrm{ml}$ of the filtrate in a $100 \mathrm{ml}$ beaker, $10 \mathrm{ml}$ of a $10 \%(\mathrm{v} / \mathrm{v}) \mathrm{HNO}_{3}$ solution was added and the mixture stirred continuously for $5 \mathrm{~min}$, while the $\mathrm{pH}$ of the mixture was maintained at 3.0 with appropriate addition of $10 \mathrm{M} \mathrm{NaOH}$ solution. The mixture was then heated at $80{ }^{\circ} \mathrm{C}$ for $1 \mathrm{hr}$ with intermittent addition of deionised water to prevent the mixture from drying up. The mixture was cooled and filtered again through Whatman No. 42 filter papers. The resulting solution was made up to $100 \mathrm{ml}$ with deionised water in a $100 \mathrm{ml}$ standard flask and $20 \mathrm{ml}$ of this solution was used for analyses by Atomic Absorption Spectrophotometer (AAS SOLAAR V10) for the elements $\mathrm{Cd}, \mathrm{Mn}, \mathrm{Pb}, \mathrm{Ni}$, and $\mathrm{Cu}$ respectively. Three repetitions were made and the mean concentration $(\mathrm{mg} / \mathrm{l})$ of HMs was obtained by the method described by Ukiwe \& Oguzie (2008). The above procedure was repeated using 30, 50, 70, and $90 \%$ $(\mathrm{v} / \mathrm{v}) \mathrm{HNO}_{3}$ respectively. However, the entire procedure was also repeated using 10, 30, 50, 70, and $90 \%(\mathrm{v} / \mathrm{v})$ $\mathrm{H}_{2} \mathrm{SO}_{4}, \mathrm{HCl}$, citric, acetic and benzoic acids respectively.

\section{Statistical Analysis}

Data are given as arithmetic mean and standard deviation. The $t$-test was used to estimate significant difference in mean concentration using $\mathrm{HCl}$ as study digestion medium.

\section{Results and Discussion}

Table 1-6 give mean concentration $(\mathrm{mg} / \mathrm{l})$ of $\mathrm{Cd}, \mathrm{Mn}, \mathrm{Pb}, \mathrm{Ni}$, and $\mathrm{Cu}$ for acid digestion of SS using inorganic acids $\left(\mathrm{HNO}_{3}, \mathrm{H}_{2} \mathrm{SO}_{4}\right.$, and $\mathrm{HCl}$ ), organic acids (citric, acetic and benzoic) at various concentrations. With the inorganic acids, $\mathrm{Mn}(4.760 \mathrm{mg} / \mathrm{l})$ was the most mobilized metal using $30 \%(\mathrm{v} / \mathrm{v}) \mathrm{HNO}_{3}$. Mn also appear to be the overall highest metal extracted totaling $(2.390,4.760,4.240,4.450$ and $2.120 \mathrm{mg} / \mathrm{l})$ using 10,30, 50, 70, and $90 \%(\mathrm{v} / \mathrm{v}) \mathrm{HNO}_{3}$ respectively. Cd was the least metal extracted using the inorganic acids. Cd extraction using $10 \%$ (v/v) $\mathrm{HNO}_{3}, \mathrm{H}_{2} \mathrm{SO}_{4}$ and $\mathrm{HCl}$ was $0.050,0.038$, and $0.039 \mathrm{mg} / 1$ respectively. $\mathrm{HCl}$ was generally observed to be the best medium for extraction of $\mathrm{Pb}, \mathrm{Ni}$, and $\mathrm{Cu}$ using both acids type at all acid concentrations, though the extraction of HMs wasn't significant between acid ranges. This is because the $t$-test between 10 and $30 \%, 30$ and $50 \%, 50$ and $70 \%$ as well as 70 and $90 \%(\mathrm{v} / \mathrm{v})$ acid concentrations are $0.14,2.71,3.59$, and 2.27 respectively. Test these values separately at 8 degrees of freedom, $\mathrm{P}<0.01$.

With the organic acids, Mn was the overall highest metal extracted. The extraction range with organic acids was $2.459,2.420,4.220,1.987$, and $2.425 \mathrm{mg} / \mathrm{l}$ respectively at $10,30,50,70$, and $90 \%(\mathrm{v} / \mathrm{v})$ acetic acid concentrations. Nevertheless, Cd was also the least metal extracted and extracted overall $(0.027 \mathrm{mg} / \mathrm{l})$ using benzoic acid at $50 \%(\mathrm{v} / \mathrm{v})$ acid concentration. It was noted in the present study that there wasn't any trend in $\mathrm{HMs}$ solubilization using the six acids types. $\mathrm{HCl}$ and acetic acids were observed to be the two most effective acids for metal extraction.

The extractive yield of HMs in sludge depend on the kind and concentration of acids used (Ukiwe \& Oguzie, 2008). Metals can be removed from sludge by acid leaching (chemical treatment). In SS metals occur in inorganic or organic complexes. In order to assess their mobility and the hazards they pose, it is necessary to distinguish their forms and assay their quantities especially the extreme toxic ones such as $\mathrm{Pb}, \mathrm{Cd}$, and $\mathrm{Zn}$. The most popular chemical extraction procedures involve treating a sample of the sludge with chemical solutions of various leaching strength (Turek et al., 2005). It has been reported that the release of HMs from SS during 
treatment with chemical reagent is strongly dependent on pH (Rajczyk \& Wiśniowska, 2005). Extraction of metals from low-grade ores, mining wastes, and SS using organic acid excreted by heterotrophic organisms was studied by Jain \& Sharma (2004). The study noted that there exist a similarity between electronic wastes and other metal containing wastes. Hence, it is expected that organic acids could also be used to leach metals from electronic wastes. Leaching capability of citric, malic, gluconic and lactic acids as well as bromine in dissolving metallic fractions of printed circuit board (PCB) wastes has been studied by Chien et al. (2000). It was revealed that the intrinsic potency of organic acids in leaching metallic fraction require decoupling the effects of secondary reactions from metal dissolution. Adsorption was shown to be the most common reaction hampering metal dissolution. However, several factors were noted to influence adsorption reaction. These include surface charge of the non-metallic fractions in $\mathrm{PCB}$, metal speciation, solution $\mathrm{pH}$, and the nature of ligands in solution. The study further revealed that although adsorption could not be completely overcome, its effect could be sufficiently suppressed by altering the solution $\mathrm{pH}$ during leaching thereby enhancing metal recovery. Removal of HMs from sludge before disposal or application to farmland is a necessary step to achieve a more safe sludge usage or disposal. Tu et al. (2011) also investigated a novel approach for leaching HMs from sludge fractions. It was shown that radiation time, power and energy had immense effect on microwave assisted extraction of HMs from SS using HEDTA (hydroxyethylenediaminetriacetic acid) and oxalic acid. By applying the Tessier's Sequential Extraction (TSC) procedure, concentration of extractable fractions of $\mathrm{Cu}, \mathrm{Ni}$, and $\mathrm{Cr}$ in sludge were increased when the microwave time, power intensity and energy density were increased. The application of chemical extraction as a part of pre-treatment method is a feasible option. A recent study examining chemical leaching process in assessing the mobility of $\mathrm{Zn}, \mathrm{Cu}, \mathrm{Cr}, \mathrm{Ni}$ and $\mathrm{Pb}$ using inorganic acids $\left(\mathrm{HNO}_{3}, \mathrm{HCl}\right)$ and organic acids (citric, oxalic) reported that solubilization of metals using inorganic acids achieved maximum extraction efficiency at $\mathrm{pH}$ value lower than 2.0 and acid contact times of $1 \mathrm{hr}$. However, using oxalic acid didn't show high extracting efficiency compared to citric acid at $\mathrm{pH} 2.0$ and $1 \mathrm{hr}$ contact time. It was further noted that citric acid appeared to be highly effective in extracting $\mathrm{Cu}$ and $\mathrm{Zn}$ at longer leaching contact times. But at $\mathrm{pH}$ 3.0, the extracting efficiency of $\mathrm{Cr}$ and $\mathrm{Cu}$ using citric acid was relatively high (Gaber et al., 2011). These results agree with the results of the present study which noted that inorganic acids were more effective in leaching HMs from SS.

\section{Conclusion}

Extraction of HMs from SS before disposal or application to farmland is a necessary step for proper sludge management. Inorganic acids have been tried successfully due to their high leaching capability, though; these acids have associated problems with environmental contamination. Nevertheless, organic acids are becoming attractive agents to overcome the problem encountered using inorganic acids for metal leaching for the following reason; organic acids are mildly acidic and biodegradable and condition pertinent for high efficiency metal solubilization. The present study has demonstrated the need for further research using organic acids to leach HMs from SS.

\section{References}

Arain, M. B., Kazi, T. G., Jamali, M. K., Baig, J. A., Afridi, H. I., Jalbini, M. K., \& Sarfraz, R. A. (2009). Comparison of different extraction approaches for heavy metal partitioning in sediment samples. Pedosphere, 19, 476-485. http://dx.doi.org/10.1016/S1002-0160(09)60140-5

Babel, S., \& Dacera, D. M. (2006). Heavy metal removal from contaminated sludge for land: a review. Waste Management, 26, 988-1004. http://dx.doi.org/10.1016/j.wasman.2005.09.017

Browski, A. D., Hubickia, Z., Cielnya, P., \& Robensb, E. (2004). Selected removal of heavy metals ions from water and industrial wastewaters by ion-exchange method. Chemosphere, 56, 91-106. http://dx.doi.org/10.1016/j.chemosphere.2004.03.006

Chien Y. C., Wang H. P., Lin, K. S., Huang Y. J., \& Yang, Y. W. (2000). Fate of bromine in pyrolysis of printed circuit board wastes. Chemosphere, 40, 383-387. http://dx.doi.org/10.1016/S0045-6535(99)00251-9

Deng, J., Feng, X., \& Qiu, X. (2009). Extraction of heavy metals from sewage sludge using ultrasound-assisted nitric acid. Chemical Engineering Journal, 152, 177-182. http://dx.doi.org/10.1016/j.cej.2009.04.031

Evangelou, M. W. H., Ebel, M., \& Schaeffer, A. (2007). Chelate assisted phytoextraction of heavy metals: effects, mechanism, toxicity, and fate of chelating agents. Chemosphere, 68, 989-1003. http://dx.doi.org/10.1016/j.chemosphere.2007.01.062

Gaber, S. E., Rizk, M. S., \& Yehia M. M. (2011). Extraction of certain heavy metals from sewage sludge using different types of acids. Biokemistri, 23, 41-48. 
Gerring, L. J. A. (1991). Mobility of $\mathrm{Cu}, \mathrm{Cd}, \mathrm{Ni}, \mathrm{Pb}, \mathrm{Zn}, \mathrm{Fe}$, and $\mathrm{Mn}$ in marine sediment slurries under anaerobic conditions and at $29 \%$ air saturation. Netherlands Journal of Sea Research, 27, 145. http://dx.doi.org/10.1016/0077-7579(91)90007-N

Harrison, E. Z., \& Oakes, R. S. (2002). Investigation of alleged health incidents associated with land application of sewage sludge. New Solutions, 12, 387-408. http://dx.doi.org/10.2190/0FJ0-T6HJ-08EM-HWW8

Jain, N., \& Sharma D. K. (2004). Biohydrometallurgy for nonsulfidic minerals-A review. Geomicrobiology, 21, 135-144. http://dx.doi.org/10.1080/01490450490275271

Loska, K., \& Wiechuła, D. (2006). Effects of $\mathrm{pH}$ and aeration on copper migration in above-sediment water. Polish Journal of Environmental Studies, 9, 433-437.

Marchioretto, M. M., Bruning, H., Loan, N. T., \& Rulkens, W. H. (2002). Heavy metals extraction from anaerobically digested sludge. Water Science and Technology, 46, 1-8.

Morita, H., \& Tsuboi, H. (2000). Basic investigation on the chemical forms of heavy metals in a sewage treatment plant. Journal of Water Science and Technology, 42, 159-165.

Naoum, C., Fatta, D., Haralambous, K. J., \& Loizidou, D. M. (2001). "Removal of heavy metals from sewage sludge by acid treatment. Journal of Environmental Science and Health, (A36), 873-881.

Peñalosa, J. M., Carpena, R. O., Vazguez, S., Agha, R., Granado, A., Sarra, M. J., \& Esteban, E. (2007). Chelate-assisted phytoextraction of heavy metals in a soil contaminated with a pyretic sludge. Science Total Enviroment, 378, 199-204. http://dx.doi.org/10.1016/j.scitotenv.2007.01.047

Pollettini, A., Pomi, R., \& Galcagnoli, G. (2008). Assisted washing for heavy metal and metalloid removal from contaminated dredged material. Water, Air, and Soil Pollution, 196, 183-198. http://dx.doi.org/10.1007/s11270-008-9767-z

Rajczyk, M. J., \& Wisniowska, E. (2005). Leaching of organic and inorganic micropollutants from chemically stabilized sewage sludge-OFMSW mixtures. Chemical Papers, 59, 453-457.

Stylianou, M. A., Kollia, D., Haralambous, K. J., Inglezakis, V. J., Moustakas, K. G., \& Loizidou, M. D. (2007). Effect of acid treatment on the removal of heavy metals from sewage sludge. Desalination, 215, 73-81. http://dx.doi.org/10.1016/j.desal.2006.11.015

Tu J., Zhao Q., \& Yang, Q. (2011). Comparative study of $\mathrm{Cu}, \mathrm{Zn}, \mathrm{Cr}, \mathrm{Ni}$, Al extraction from sewage sludge with six kinds of acids at low concentration. In: Proceedings of International Symposium on Resource and Environmental Protection. China. 1607-1610. http://dx.doi.org/10.1109/ISWREP.2011.5893229

Turek, M., Korolewicz, T., \& Ciba, J. (2005). Removal of heavy metals from sewage sludge used as soil fertilizer. Soil and Sediment Contamination, 14, 143-154. http://dx.doi.org/10.1080/15320380590911797

Ukiwe, L. N., \& Iwu, I. C. (2010). Effect of reaction time and acids in chemical leaching of heavy metals in sewage sludge. Terrestrial and Aquatic Environmental Toxicology, 5, 73-76.

Ukiwe, L. N., \& Nwoko, C. I. A. (2010a). The influence of acids and pH in removal efficiency of heavy metals by inorganic coagulants. Terrestrial and Aquatic Environmental Toxicology, 5, 65-68.

Ukiwe, L. N., \& Nwoko, C. I. A. (2010b). Effect of aeration and acidification on heavy metals solubilization of sewage sludge. Terrestrial and Aquatic Environmental Toxicology, 5, 69-72.

Ukiwe, L. N., \& Oguzie, E. E. (2008). Effect of pH and acid on heavy metal solubilization of domestic sewage sludge. Terrestrial and Aquatic Environmental Toxicology, 2, 54-58.

Ukiwe, L. N., Nwoko, C. I. A. \& Nkwocha, E. E. (2010). Heavy metals solubilization in EDTA assisted remediation of sewage sludge. Terrestrial and Aquatic Environmental Toxicology, 5, 47-50.

UNEP-United Nations Environmental Programme. (2004). Wastewater treatment: The municipal sludge production process. Available online: http//:www.epa.gov

Yoshizaki, S., \& Tomida, T. (2000). Principle and process of heavy metal removal from sewage sludge. Environmental Science and Technology, 34, 1572-1575. http://dx.doi.org/10.1021/es990979s

Zhang, H., Zhu, Z. H., Zhang, L. H., \& Zhao, J. F. (2008). Extraction of heavy metals from sewage sludge using aspartic and citric acid. Journal of Environmental Science, 29, 733-737. 
Table 1. Concentration (mg/l) of $\mathrm{HMs}$ in sewage digestate using $\mathrm{HNO}_{3}$

\begin{tabular}{|c|c|c|c|c|c|}
\hline \multirow{2}{*}{$\begin{array}{r}\text { Extractant } \\
\text { concentration }\end{array}$} & $10 \%(\mathrm{v} / \mathrm{v})$ & $30 \%(\mathrm{v} / \mathrm{v})$ & $50 \%(\mathrm{v} / \mathrm{v})$ & $70 \%(\mathrm{v} / \mathrm{v})$ & $90 \%(\mathrm{v} / \mathrm{v})$ \\
\cline { 2 - 7 } & $\begin{array}{c}\text { Mean }(\mathrm{mg} / \mathrm{l}) \pm \\
\mathrm{SD}\end{array}$ & $\begin{array}{c}\text { Mean }(\mathrm{mg} / \mathrm{l}) \pm \\
\mathrm{SD}\end{array}$ & $\begin{array}{c}\text { Mean }(\mathrm{mg} / \mathrm{l}) \pm \\
\mathrm{SD}\end{array}$ & $\begin{array}{c}\text { Mean }(\mathrm{mg} / \mathrm{l}) \pm \\
\mathrm{SD}\end{array}$ & $\begin{array}{c}\text { Mean }(\mathrm{mg} / \mathrm{l}) \pm \\
\mathrm{SD}\end{array}$ \\
\hline $\mathrm{Cd}$ & $0.050 \pm 0.0$ & $0.050 \pm 0.0$ & $0.060 \pm 0.0$ & $0.050 \pm 0.0$ & $0.040 \pm 0.0$ \\
\hline $\mathrm{Mn}$ & $2.390 \pm 0.2$ & $4.760 \pm 0.3$ & $4.240 \pm 0.1$ & $4.450 \pm 0.8$ & $2.120 \pm 0.5$ \\
\hline $\mathrm{Pb}$ & $0.110 \pm 0.0$ & $0.090 \pm 0.0$ & $0.120 \pm 0.0$ & $0.082 \pm 0.0$ & $0.040 \pm 0.0$ \\
\hline $\mathrm{Ni}$ & $0.080 \pm 0.0$ & $0.060 \pm 0.0$ & $0.090 \pm 0.0$ & $0.090 \pm 0.0$ & $0.140 \pm 0.0$ \\
\hline $\mathrm{Cu}$ & $0.140 \pm 0.0$ & $0.010 \pm 0.0$ & $0.280 \pm 0.0$ & $0.130 \pm 0.0$ & $0.100 \pm 0.0$ \\
\hline
\end{tabular}

Table 2. Concentration (mg/l) of HMs in sewage digestate using $\mathrm{H}_{2} \mathrm{SO}_{4}$

\begin{tabular}{|c|c|c|c|c|c|}
\hline \multirow{2}{*}{$\begin{array}{r}\text { Extractant } \\
\text { concentration }\end{array}$} & $10 \%(\mathrm{v} / \mathrm{v})$ & $30 \%(\mathrm{v} / \mathrm{v})$ & $50 \%(\mathrm{v} / \mathrm{v})$ & $70 \%(\mathrm{v} / \mathrm{v})$ & $90 \%(\mathrm{v} / \mathrm{v})$ \\
\cline { 2 - 6 } & $\begin{array}{c}\text { Mean }(\mathrm{mg} / \mathrm{l}) \pm \\
\mathrm{SD}\end{array}$ & $\begin{array}{c}\text { Mean }(\mathrm{mg} / \mathrm{l}) \pm \\
\mathrm{SD}\end{array}$ & $\begin{array}{c}\text { Mean }(\mathrm{mg} / \mathrm{l}) \pm \\
\mathrm{SD}\end{array}$ & $\begin{array}{c}\text { Mean }(\mathrm{mg} / \mathrm{l}) \pm \\
\mathrm{SD}\end{array}$ & $\begin{array}{c}\mathrm{Mean}(\mathrm{mg} / \mathrm{l}) \pm \\
\mathrm{SD}\end{array}$ \\
\hline $\mathrm{Cd}$ & $0.038 \pm 0.0$ & $0.044 \pm 0.0$ & $0.051 \pm 0.0$ & $0.056 \pm 0.0$ & $0.045 \pm 0.0$ \\
\hline $\mathrm{Mn}$ & $1.619 \pm 0.5$ & $2.683 \pm 0.6$ & $2.981 \pm 0.6$ & $2.087 \pm 0.5$ & $3.013 \pm 0.7$ \\
\hline $\mathrm{Pb}$ & $0.766 \pm 0.1$ & $0.307 \pm 0.0$ & $0.042 \pm 0.0$ & $0.421 \pm 0.1$ & $1.139 \pm 0.3$ \\
\hline $\mathrm{Ni}$ & $0.048 \pm 0.0$ & $0.084 \pm 0.0$ & $0.054 \pm 0.0$ & $0.049 \pm 0.0$ & $0.255 \pm 0.0$ \\
\hline $\mathrm{Cu}$ & $0.219 \pm 0.0$ & $0.476 \pm 0.1$ & $0.433 \pm 0.1$ & $0.337 \pm 0.1$ & $0.453 \pm 0.1$ \\
\hline
\end{tabular}

Table 3. Concentration (mg/l) of HMs in sewage digestate using $\mathrm{HCl}$

\begin{tabular}{|c|c|c|c|c|c|}
\hline \multirow{2}{*}{$\begin{array}{r}\text { Extractant } \\
\text { concentration }\end{array}$} & $10 \%(\mathrm{v} / \mathrm{v})$ & $30 \%(\mathrm{v} / \mathrm{v})$ & $50 \%(\mathrm{v} / \mathrm{v})$ & $70 \%(\mathrm{v} / \mathrm{v})$ & $90 \%(\mathrm{v} / \mathrm{v})$ \\
\cline { 2 - 7 } & $\begin{array}{c}\text { Mean }(\mathrm{mg} / \mathrm{l}) \pm \\
\mathrm{SD}\end{array}$ & $\begin{array}{c}\text { Mean }(\mathrm{mg} / \mathrm{l}) \pm \\
\mathrm{SD}\end{array}$ & $\begin{array}{c}\text { Mean }(\mathrm{mg} / \mathrm{l}) \pm \\
\mathrm{SD}\end{array}$ & $\begin{array}{c}\text { Mean }(\mathrm{mg} / \mathrm{l}) \pm \\
\mathrm{SD}\end{array}$ & $\begin{array}{c}\text { Mean }(\mathrm{mg} / \mathrm{l}) \pm \\
\mathrm{SD}\end{array}$ \\
\hline $\mathrm{Cd}$ & $0.039 \pm 0.0$ & $0.042 \pm 0.0$ & $0.041 \pm 0.0$ & $0.042 \pm 0.0$ & $0.046 \pm 0.0$ \\
\hline $\mathrm{Mn}$ & $2.834 \pm 0.7$ & $2.587 \pm 0.7$ & $3.491 \pm 0.5$ & $2.776 \pm 0.5$ & $3.582 \pm 0.6$ \\
\hline $\mathrm{Pb}$ & $3.516 \pm 0.6$ & $3.722 \pm 0.8$ & $3.661 \pm 0.2$ & $3.462 \pm 0.5$ & $3.557 \pm 0.2$ \\
\hline $\mathrm{Ni}$ & $2.456 \pm 0.4$ & $2.134 \pm 0.3$ & $2.684 \pm 0.2$ & $2.087 \pm 0.8$ & $2.662 \pm 0.2$ \\
\hline $\mathrm{Cu}$ & $1.983 \pm 0.6$ & $2.272 \pm 0.7$ & $2.895 \pm 0.7$ & $1.222 \pm 0.6$ & $1.769 \pm 0.2$ \\
\hline
\end{tabular}

Table 4. Concentration (mg/l) of HMs in sewage digestate using acetic acid

\begin{tabular}{|c|c|c|c|c|c|}
\hline \multirow{2}{*}{$\begin{array}{c}\text { Extractant } \\
\text { concentration }\end{array}$} & $10 \%(\mathrm{v} / \mathrm{v})$ & $30 \%(\mathrm{v} / \mathrm{v})$ & $50 \%(\mathrm{v} / \mathrm{v})$ & $70 \%(\mathrm{v} / \mathrm{v})$ & $90 \%(\mathrm{v} / \mathrm{v})$ \\
\cline { 2 - 6 } & $\begin{array}{c}\text { Mean }(\mathrm{mg} / \mathrm{l}) \pm \\
\mathrm{SD}\end{array}$ & $\begin{array}{c}\text { Mean }(\mathrm{mg} / \mathrm{l}) \pm \\
\mathrm{SD}\end{array}$ & $\begin{array}{c}\text { Mean }(\mathrm{mg} / \mathrm{l}) \pm \\
\mathrm{SD}\end{array}$ & $\begin{array}{c}\text { Mean }(\mathrm{mg} / \mathrm{l}) \pm \\
\mathrm{SD}\end{array}$ & $\begin{array}{c}\mathrm{Mean}(\mathrm{mg} / \mathrm{l}) \pm \\
\mathrm{SD}\end{array}$ \\
\hline $\mathrm{Cd}$ & $0.034 \pm 0.0$ & $0.044 \pm 0.0$ & $0.028 \pm 0.0$ & $0.043 \pm 0.0$ & $0.036 \pm 0.0$ \\
\hline $\mathrm{Mn}$ & $2.459 \pm 0.1$ & $2.420 \pm 0.4$ & $4.220 \pm 0.7$ & $1.987 \pm 0.6$ & $2.425 \pm 0.5$ \\
\hline $\mathrm{Pb}$ & $0.273 \pm 0.1$ & $0.237 \pm 0.2$ & $0.241 \pm 0.0$ & $0.203 \pm 0.0$ & $1.185 \pm 0.7$ \\
\hline $\mathrm{Ni}$ & $0.104 \pm 0.0$ & $0.082 \pm 0.0$ & $0.086 \pm 0.0$ & $0.082 \pm 0.0$ & $0.190 \pm 0.0$ \\
\hline $\mathrm{Cu}$ & $0.519 \pm 0.1$ & $0.788 \pm 0.1$ & $0.223 \pm 0.0$ & $0.630 \pm 0.1$ & $0.558 \pm 0.1$ \\
\hline
\end{tabular}


Table 5. Concentration (mg/l) of HMs in sewage digestate using benzoic acid

\begin{tabular}{|c|c|c|c|c|c|}
\hline \multirow{2}{*}{$\begin{array}{r}\text { Extractant } \\
\text { concentration }\end{array}$} & $10 \%(\mathrm{v} / \mathrm{v})$ & $30 \%(\mathrm{v} / \mathrm{v})$ & $50 \%(\mathrm{v} / \mathrm{v})$ & $70 \%(\mathrm{v} / \mathrm{v})$ & $90 \%(\mathrm{v} / \mathrm{v})$ \\
\cline { 2 - 6 } & $\begin{array}{c}\text { Mean }(\mathrm{mg} / \mathrm{l}) \pm \\
\mathrm{SD}\end{array}$ & $\begin{array}{c}\text { Mean }(\mathrm{mg} / \mathrm{l}) \pm \\
\mathrm{SD}\end{array}$ & $\begin{array}{c}\text { Mean }(\mathrm{mg} / \mathrm{l}) \pm \\
\mathrm{SD}\end{array}$ & $\begin{array}{c}\text { Mean }(\mathrm{mg} / \mathrm{l}) \pm \\
\mathrm{SD}\end{array}$ & $\begin{array}{c}\text { Mean }(\mathrm{mg} / \mathrm{l}) \pm \\
\mathrm{SD}\end{array}$ \\
\hline $\mathrm{Cd}$ & $0.047 \pm 0.0$ & $0.055 \pm 0.0$ & $0.027 \pm 0.0$ & $0.036 \pm 0.0$ & $0.041 \pm 0.0$ \\
\hline $\mathrm{Mn}$ & $0.180 \pm 0.0$ & $0.203 \pm 0.0$ & $0.225 \pm 0.0$ & $0.385 \pm 0.1$ & $0.350 \pm 0.6$ \\
\hline $\mathrm{Pb}$ & $0.345 \pm 0.0$ & $0.377 \pm 0.2$ & $0.398 \pm 0.3$ & $0.387 \pm 0.1$ & $0.451 \pm 0.5$ \\
\hline $\mathrm{Ni}$ & $0.276 \pm 0.0$ & $0.246 \pm 0.1$ & $0.239 \pm 0.1$ & $0.219 \pm 0.0$ & $0.214 \pm 0.0$ \\
\hline $\mathrm{Cu}$ & $0.189 \pm 0.0$ & $0.269 \pm 0.2$ & $0.240 \pm 0.0$ & $0.235 \pm 0.0$ & $0.248 \pm 0.1$ \\
\hline
\end{tabular}

Table 6. Concentration (mg/l) of HMs in sewage digestate using citric acid

\begin{tabular}{|c|c|c|c|c|c|}
\hline \multirow{2}{*}{$\begin{array}{c}\text { Extractant } \\
\text { concentration }\end{array}$} & $10 \%(\mathrm{v} / \mathrm{v})$ & $30 \%(\mathrm{v} / \mathrm{v})$ & $50 \%(\mathrm{v} / \mathrm{v})$ & $70 \%(\mathrm{v} / \mathrm{v})$ & $90 \%(\mathrm{v} / \mathrm{v})$ \\
\cline { 2 - 6 } & $\begin{array}{c}\text { Hean }(\mathrm{mg} / \mathrm{l}) \pm \\
\mathrm{SD}\end{array}$ & $\begin{array}{c}\text { Mean }(\mathrm{mg} / \mathrm{l}) \pm \\
\mathrm{SD}\end{array}$ & $\begin{array}{c}\text { Mean }(\mathrm{mg} / \mathrm{l}) \pm \\
\mathrm{SD}\end{array}$ & $\begin{array}{c}\text { Mean }(\mathrm{mg} / \mathrm{l}) \pm \\
\mathrm{SD}\end{array}$ & $\begin{array}{c}\mathrm{Mean}(\mathrm{mg} / \mathrm{l}) \pm \\
\mathrm{SD}\end{array}$ \\
\hline $\mathrm{Cd}$ & $0.050 \pm 0.0$ & $0.070 \pm 0.0$ & $0.050 \pm 0.0$ & $0.050 \pm 0.0$ & $0.060 \pm 0.0$ \\
\hline $\mathrm{Mn}$ & $0.103 \pm 0.0$ & $0.137 \pm 0.0$ & $0.174 \pm 0.1$ & $0.379 \pm 0.3$ & $0.293 \pm 0.1$ \\
\hline $\mathrm{Pb}$ & $0.423 \pm 0.7$ & $0.216 \pm 0.0$ & $0.285 \pm 0.3$ & $0.479 \pm 0.4$ & $0.488 \pm 0.7$ \\
\hline $\mathrm{Ni}$ & $0.100 \pm 0.0$ & $0.090 \pm 0.0$ & $0.050 \pm 0.0$ & $0.100 \pm 0.0$ & $0.090 \pm 0.0$ \\
\hline $\mathrm{Cu}$ & $0.143 \pm 0.0$ & $0.168 \pm 0.0$ & $0.127 \pm 0.0$ & $0.213 \pm 0.0$ & $0.249 \pm 0.2$ \\
\hline
\end{tabular}

